\title{
An enigmatic Arthropoda from the Upper Triassic (Carnian) southwestern Gondwana (Argentina)
}

\author{
María B. Lara, ${ }^{1}$ (1) Bárbara Cariglino, ${ }^{2}$ Ana M. Zavattieri, ${ }^{3}$ and Iracema Zacarías ${ }^{1}$ \\ ${ }^{1}$ Área Paleontología, Centro de Ecología Aplicada del Litoral-CECOAL-CCT-Nordeste-CONICET, Casilla de Correo 128,3400 \\ Corrientes, Argentina <lara.maria.belen@live.com.ar><iracemaz@gmail.com> \\ ${ }^{2}$ Área de Paleobotánica y Paleopalinología, Museo Argentino de Ciencias Naturales 'Bernardino Rivadavia,' Consejo Nacional de \\ Investigaciones Científicas y Técnicas, Av. Ángel Gallardo 470, C1405DJR, Ciudad Autónoma de Buenos Aires, Argentina \\ $<$ barichi10@gmail.com> \\ ${ }^{3}$ Departamento de Paleontología, Instituto Argentino de Nivología, Glaciología y Ciencias Ambientales IANIGLA, CCT-CONICET \\ Mendoza, Av. Adrián Ruiz Leal s/n, Parque General San Martín, (M5502 IRA) Mendoza, Casilla de Correo 330, Mendoza, Argentina \\ $<$ amz@mendoza-conicet.gob.ar>
}

\begin{abstract}
The presence of a new taxon, Duraznovis gallegoi new genus new species is reported and described from an early Late Triassic (Carnian) deposit in Argentina. Two specimens, recovered from the Quebrada del Durazno locality, uppermost levels of the Potrerillos Formation, Cuyana Basin (Mendoza), are represented by the molds of their shield and imprints of soft parts. The identity of these specimens appears enigmatic but closely resembles in the possession of a generalized arthropod morphology and a distinctive combination of characters, to living and fossil representatives of xiphosurans (Chelicerata) and notostracans (Branchiopoda). The new fossils are associated with a rich biota comprising abundant insects, spinicaudatans, plants, and scarce fish remains living in semipermanent swamps and/or ponds within a delta plain environment with intermittent episodes of flooding, in a warm temperate and humid megamonsoonal climate during Triassic times. In this context, we analyze the taphonomic and ecological implications of their presence. Lastly, these unique specimens at the Quebrada del Durazno locality adds to the diversity of the biota, revealing the importance of this site as an exceptional paleontological Triassic deposit.
\end{abstract}

UUID: http://zoobank.org/8d1194c2-170c-4b7a-b0c6-5c08b0974d95

\section{Introduction}

In Argentina, invertebrate records represent an important component of the continental Mesozoic faunas, and are typified mainly by arthropods (spinicaudatans = 'conchostracans,' insects, and ostracods) and freshwater mollusks (bivalves and gastropods) (e.g., Papú, 1993; Morton and Herbst, 2001; Camacho and Del Río, 2007; Griffin and Varela, 2012; Parras and Griffin, 2013; Lara et al., 2017; Carignano and Zavattieri, 2018; Carignano et al., 2018). The highest diversity of continental fossil invertebrates from the Argentinean Triassic sequences derives mainly from two basins: (1) the Ischigualasto-Villa Unión Basin (= Bermejo Basin) in La Rioja and San Juan provinces, and (2) the Cuyana Basin (= Cuyo Basin) in Mendoza and San Juan provinces. In these basins, the most common and best-studied fossil invertebrates comprise the insects, with 87 described species (Martins-Neto et al., 2003, 2005, 2006a, b, 2007, 2008; Martins-Neto and Gallego, 2009; Gallego et al., 2011; Lara and Lukashevich, 2013; Lara et al., 2014, 2015, 2017; Lara, 2016; Lara and Aristov, 2016; Lara and Wang, 2016), and the spinicaudatans, with 30 described species (Rusconi, 1946a, b, 1947, 1948a, b; Tasch, 1987; Gallego, 1992, 1999, 2005; Camacho, 1995; Shen et al., 2001; Gallego et al., 2004; Tassi et al., 2013, 2015; Tassi, 2016).
For the Triassic, data on continental aquatic arthropods (with the exception of spinicaudatans) from South America are scarce and usually referred as first-record mentions in different reports. Aside from those records, Covacevich et al. (1988) revealed fragmentary notostracan remains (abdomen, telson, and caudal furca) belonging to Triops Schrank, 1803 from the Triassic Pular Formation (Sierra de Almeida, Antofagasta), Chile. Martins-Neto et al. (2001) mentioned the presence of several undescribed crustaceans (isolated carapaces) referred to notostracan or kazacharthan-like specimens from the Ischichuca/Los Rastros formations (Ladinian-Carnian), in the Ischigualasto-Villa Unión Basin, central-western Argentina, but such material has not been described in detail. Recently, Carignano and Zavattieri (2018) and Carignano et al. (2018) reported Triassic ostracods (Darwinulocopina) from the Cerro de Las Cabras Formation, in the Potrerillos area, Mendoza. However, the paucity of information about freshwater arthropods is more probably a consequence of the lack of fieldwork and studies oriented to the search of these faunas than to the real absence of these taxa in South American deposits.

From three fieldwork seasons (2015-2017) at the Quebrada del Durazno locality, uppermost section of the Potrerillos Formation (Carnian), south of the Cerro Cacheuta, in Mendoza Province, Argentina, more than one thousand fossils were recovered, including abundant plants (typical of the Dicroidium 
Flora), diverse insects (attributable mainly to hemipterans, and in less proportions odonatans, mecopterans, miomopterans, grylloblattids, dipterans, beetles, and orthopterans), plant-insect interactions (holes, marginal and surface feeding, piercing and sucking, and oviposition), numerous spinicaudatans (e.g., Euestheria forbesi Jones, 1863 (Gallego, 1992, 1999), and few fish remains (cf. Neochallaia sp.) (Lara, 2016; Lara et al., 2017), most of which are preserved in remarkable detail. The uppermost levels of the Potrerillos Formation at the Quebrada del Durazno locality are interpreted as semipermanent swamp/ lacustrine bodies within a delta plain environment, which were affected by occasional flooding from distributary channels/ streams, allowing the development of incipient palaeosols (Lara et al., 2017). As the latest novelty from this locality, we report and describe here two enigmatic specimens with arthropod-related traits. Besides providing morphological information about invertebrate anatomy, this new discovery allows us to add information about taphonomic and paleoenvironmental conditions at the Quebrada del Durazno during Triassic times, providing insights about the ecosystems in which the biota lived.

\section{Geological and stratigraphic setting}

The Cuyana Basin (also named 'Cuyo Basin') is the largest continental rift basin in central western Argentina ( $>400 \mathrm{~km}$ northwest strike) formed obliquely on the southwestern margin of southern South America. The Triassic continental rift basins of western Argentina are product of the Triassic extensional phase developed at the beginning of the Mesozoic Gondwana breakup (Uliana and Biddle, 1988; Ramos, 1992; López Gamundí, 1994, 2010; Barredo, 2012). The NNW-SSE trending, narrow, asymmetric Cuyana Basin is filled with a thick sedimentary sequence of siliciclastic rocks interbedded with tuffs of coeval volcanics constituting all together the Uspallata Group (Stipanicic and Zavattieri, 2002). The Cuyana Basin also includes a series of unconnected, asymmetric, fault-bounded depocenters or sub-basins with a half-graben geometry. The Cacheuta Sub-basin (also called Potrerillos-Cacheuta depocenter) represents the westernmost portion of the Cuyana Basin with numerous well-exposed Triassic sections. The initial sedimentary fill of the Potrerillos-Cacheuta depocenter is characterized by basal coarse clastic fan and playa-lake facies (Río Mendoza and Cerro de Las Cabras formations) that grade upward to cross-bedded sandstones, shales, scarce conglomerates, and tuffs deposited in the braided-river systems of the lower to middle part of the Potrerillos Formation to the deltaic systems in the upper part of the unit. The fluvio-deltaic systems of the Potrerillos Formation grade upward to into the widespread, euxinic, lacustrine, bituminous shales of the Cacheuta Formation succeeded in turn unconformably by a second fluvial sequence represented by Río Blanco Formation. The PotrerillosCacheuta depocenter contains the thickest and most prolific source rocks of the basin (Chebli et al., 1984, 2001; López Gamundí, 2010). Most of the sedimentary units of the Uspallata Group have the most diverse fossil content of the entire Cuyana Basin (Stipanicic and Zavattieri, 2002; Lara et al., 2017).

The material studied herein comes from the uppermost strata of the Potrerillos Formation at the Quebrada del Durazno locality $\left(33^{\circ} 4^{\prime} \mathrm{S}, 69^{\circ} 7^{\prime} \mathrm{W}\right)$, south of the Cerro Cacheuta,
Potrerillos-Cacheuta depocenter, Mendoza Province, Argentina (Figs. 1, 2). The basal and middle parts of the Potrerillos Formation are not exposed in the Quebrada del Durazno section. The uppermost outcropping section of the unit in this locality is interpreted as deltaic systems represented by greenish grey, laminated siltstones and sandstones, interbedded with black bituminous shales and tuffs from which the studied specimens were recovered. These facies laterally interfinger with, or are covered by, the widespread lacustrine black shales of the Cacheuta Formation. The whole Potrerillos Formation is constrained to a latest Middle Triassic (late Ladinian) to early Upper Triassic (Carnian) age. Spalletti et al. (2008) determined UVPb SHRIMP $239.2 \pm 4.5 \mathrm{Ma}, 239.7 \pm 2.2 \mathrm{Ma}$ ages on tuff beds from the base of the unit at the Potrerillos locality. This is also supported by palynological evidence, ranging in age as a whole from late Ladinian to Carnian (Zavattieri and Batten, 1996). The levels bearing these enigmatic arthropods and associated fauna (spinicaudatans and insects) of the uppermost part of the Potrerillos Formation at the south of the Cacheuta hill is referred to Carnian age based on palynological evidence (Zavattieri and Rojo, 2005; Zavattieri and Prámparo, 2006). Lara et al. (2017) described the sedimentary sequence and its paleoenvironmental and paleoecological reconstruction of the Triassic Quebrada del Durazno section (Potrerillos Formation) based on fossil insect, paleobotanical, and sedimentological records.

\section{Material and methods}

The fossils studied herein include two completely articulated specimens, preserved as a 3D mold (holotype) and a compression (paratype) (Figs. 3, 4). The specimens were photographed under strong unilateral light at different angles to enhance their surface features using a Nikon DS-Fi1-U2 digital camera attached to a Nikon SMZ800 stereomicroscope. Measurements were performed with ImageJ $1.49 \mathrm{v}$ software.

Repository and institutional abbreviation.-The collected material is housed at the Instituto Argentino de Nivología, Glaciología y Ciencias Ambientales-Centro Científico Tecnológico-Consejo Nacional de Investigaciones Científicas y Técnicas (IANIGLA-CCT-CONICET) in Mendoza Province (IANIGLA-PB).

\section{Systematic paleontology}

\author{
Phylum Arthropoda Latreille, 1829 \\ Order Incertae sedis \\ Family Incertae sedis
}

Genus Duraznovs new genus

Type species.-Duraznovis gallegoi new species; by monotypy.

Diagnosis.-Body differentiated into anterior and posterior regions. Shield with a guitar-shaped outline in dorsoventral view, with a semicircular anterior margin and lateral margins oblique to the median body axis, proximally wide and tapering distally at an angle of $70-74^{\circ}$. Anterior region completely covered by the shield, with six visible segments. 


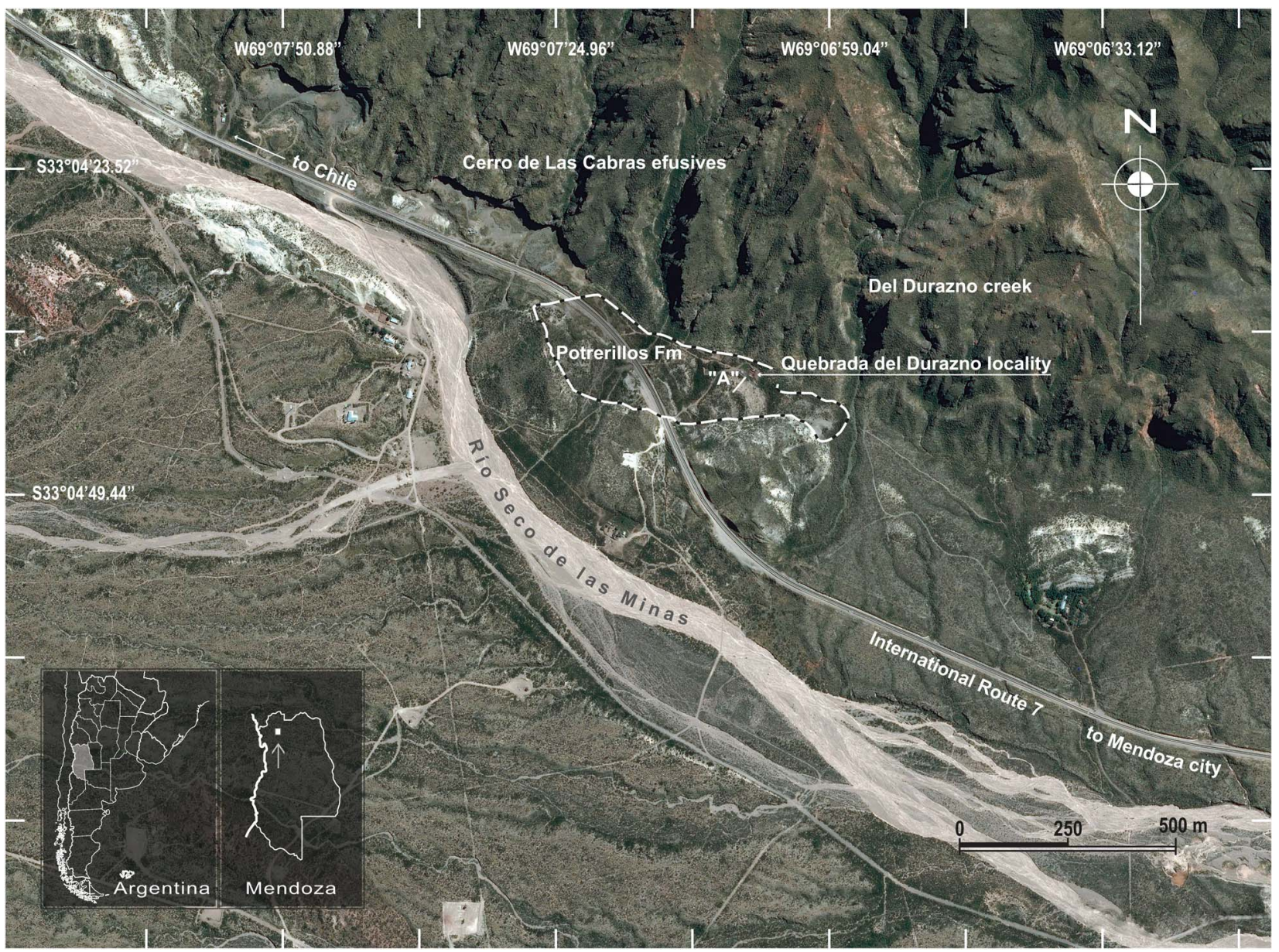

Figure 1. Aerial view of the southern flank of the Cerro Cacheuta, Mendoza Province, Argentina, showing the studied section ('A') of the Potrerillos Formation (Carnian) at the Quebrada del Durazno locality. Modified from Lara et al. (2017).

Posterior region characterized by a broad, trapezoidal, apparently unsegmented, weakly bulging, apodous abdomen. Finally, a long, styliform tail-like structure is inserted in the center of the posterior area and is distally divided.

Occurrence.-Quebrada del Durazno locality, Potrerillos Formation (upper section), lower Upper Triassic (Carnian), south of the Cerro Cacheuta, Potrerillos-Cacheuta depocenter of the Cuyana Basin, Mendoza Province, Argentina.

Etymology.-Named after the Quebrada del Durazno locality and from the Latin novis $=$ new.

Remarks.-Duraznovis n. gen. is placed in Arthropoda based on a tagmatised body and ventral segmentation indicating the placement of appendages.

\section{Duraznovis gallegoi new species}

Figures 3-5

Type material.-IANIGLA-PB 203 (holotype); IANIGLA-PB 168 (paratype).

Diagnosis.—See generic diagnosis above.
Occurrence.-Quebrada del Durazno locality, Potrerillos Formation (upper section), lower Upper Triassic (Carnian), south of the Cerro Cacheuta, Potrerillos-Cacheuta depocenter of the Cuyana Basin, Mendoza Province, Argentina.

Description.-Holotype IANIGLA-PB 203 (Figs. 3, 5.1) is three-dimensionally preserved, retaining part of its original volume in ventral view. The total length of the specimen is $7 \mathrm{~mm}$, and it is $3.4 \mathrm{~mm}$ at its broadest part. The body is differentiated into an anterior region (Fig. 5.1, An), and a posterior region (Fig. 5.1, Po). A hard, protective, guitarshaped shield (S) covers the body $(2.57 \mathrm{~mm}$ long, $3.4 \mathrm{~mm}$ wide) representing approximately half of the body length (tail-like structure [Ta] excluded). The shield (Fig. 5.1, S) is nearly completely preserved, with a semicircular anterior margin, and lateral margins oblique to the median axis at an angle of $74^{\circ}$. Impressions of undetermined structures are visible on the upper part of the anterior region (Fig. 5.1, a). A protuberant area $(1.71 \mathrm{~mm})$ is visible, completely covered by the shield (Figs. $3 ; 5.1$, b). It has six segments (Figs. 3, I-VI, 5.1, se) that probably carried six paired structures, or 'appendages.' The posterior region (Fig. 5.1, Po) is $1.71 \mathrm{~mm}$ long and consists of a broad, trapezoidal, apparently unsegmented, weakly bulging, 


\section{QUEBRADA DEL DURAZNOSECTION}

(m)

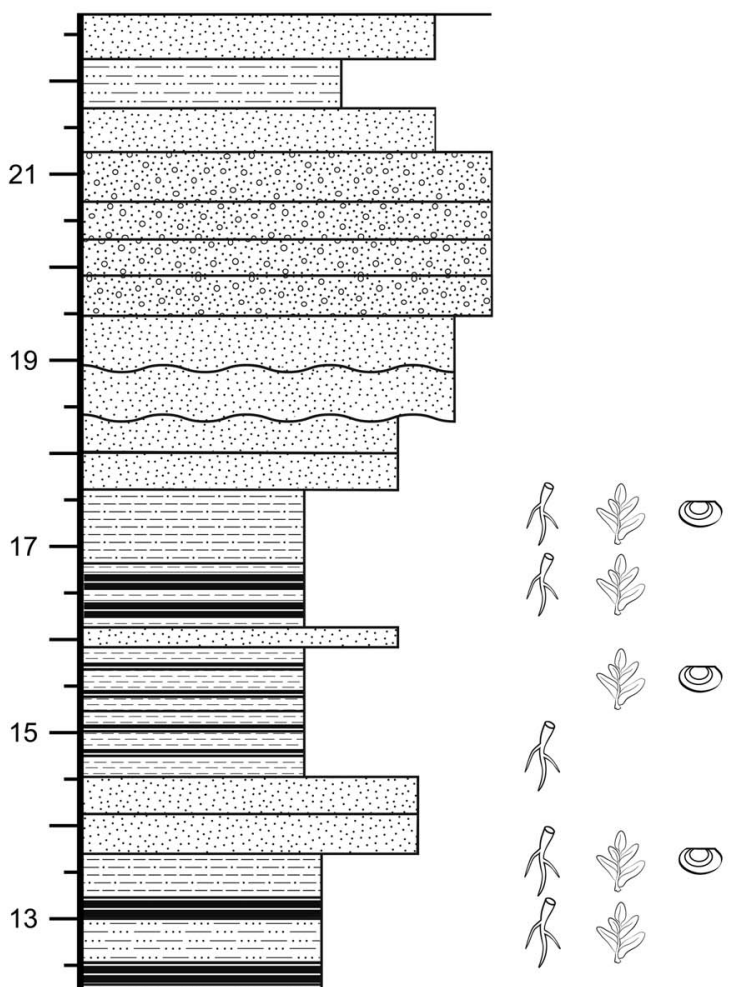

LITHOLOGY

Fine conglomerate

Sandstone

Siltstone

Claystone

11

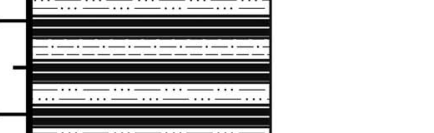

$\Gamma$

Tuffaceous siltstone and mudstone

Organic shale

Coal

Bentonite

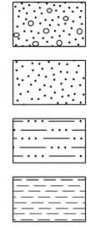

09

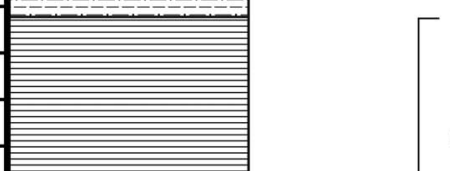

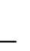
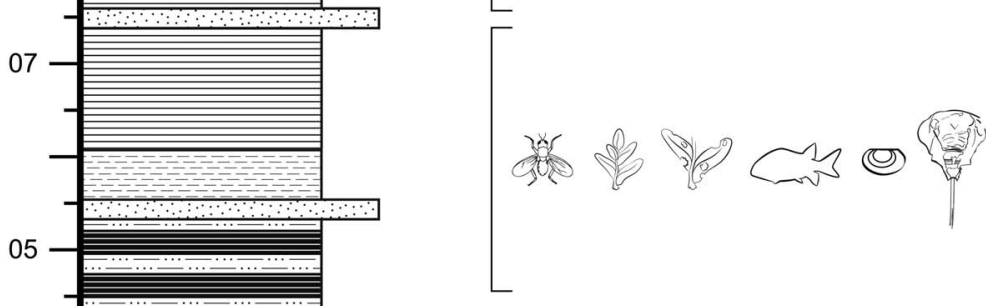

FOSSILS
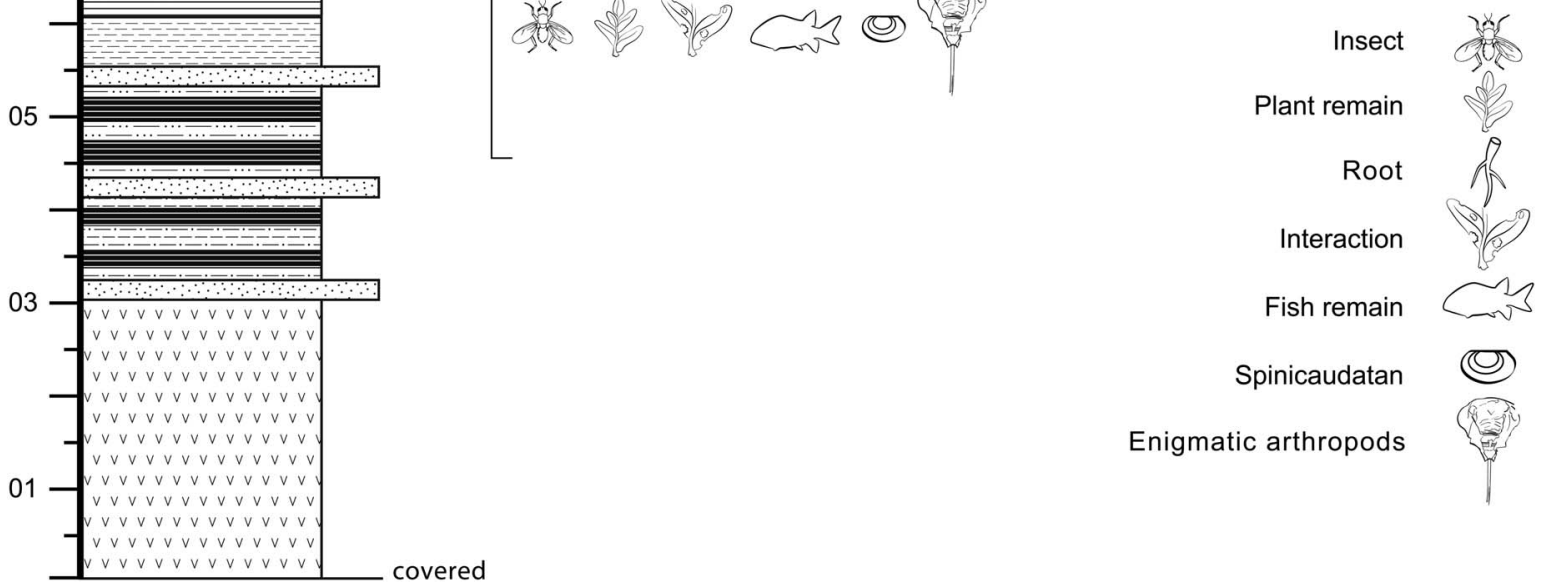

Fish remain

Spinicaudatan (0)

Enigmatic arthropods

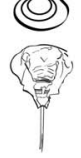

Figure 2. Sedimentologic profile of the Potrerillos Formation outcrops (Carnian) at the Quebrada del Durazno locality, south of the Cerro Cacheuta, Mendoza Province, Argentina, indicating the fossil levels bearing the enigmatic arthropods herein described. Modified from Lara et al. (2017). 

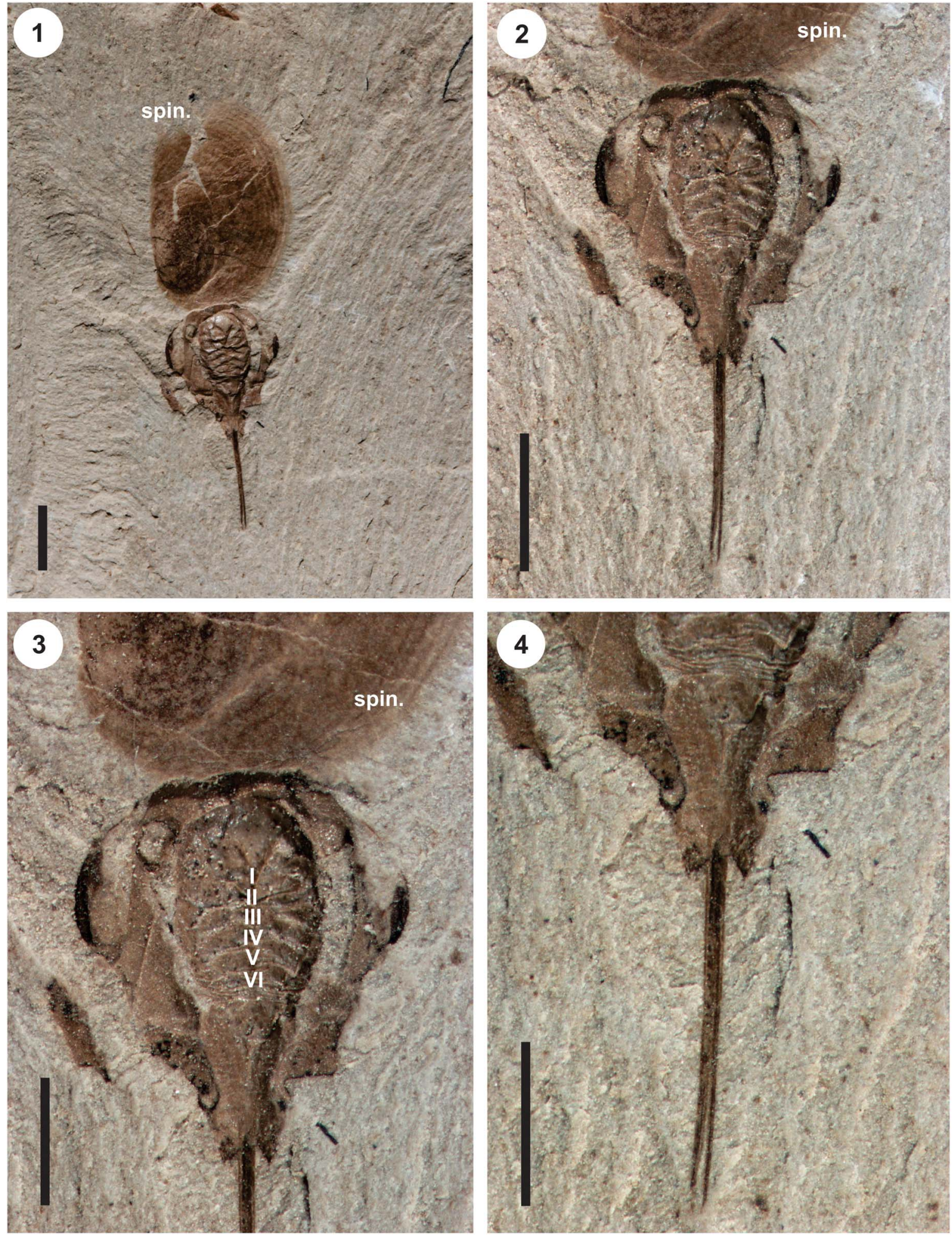

Figure 3. Duraznovis gallegoi n. gen. n. sp. from Potrerillos Formation, Cuyana Basin, Mendoza, Argentina, holotype, IANIGLA-PB 203, complete specimen in ventral view: $(\mathbf{1})$ entire specimen; $(\mathbf{2}, \mathbf{3})$ detail showing the morphological characters; $(\mathbf{4})$ detail of posterior region and tail. I-VI= potential paired appendages; spin. $=$ spinicaudatans. Scale bars $=2 \mathrm{~mm}$.

apodous area. Toward the end, there is an area with a W-shaped posterior margin in which a long, styliform, distally divided tail-like structure $(2.94 \mathrm{~mm})$ is inserted (Fig. 5.1, Ta).
Paratype IANIGLA-PB 168 (Figs. 4, 5.2) is a moderately preserved compression, however, its main morphological features can still be recognized. Like the holotype, the body can be discerned as an anterior region (Fig. 5.2, An) and a posterior 

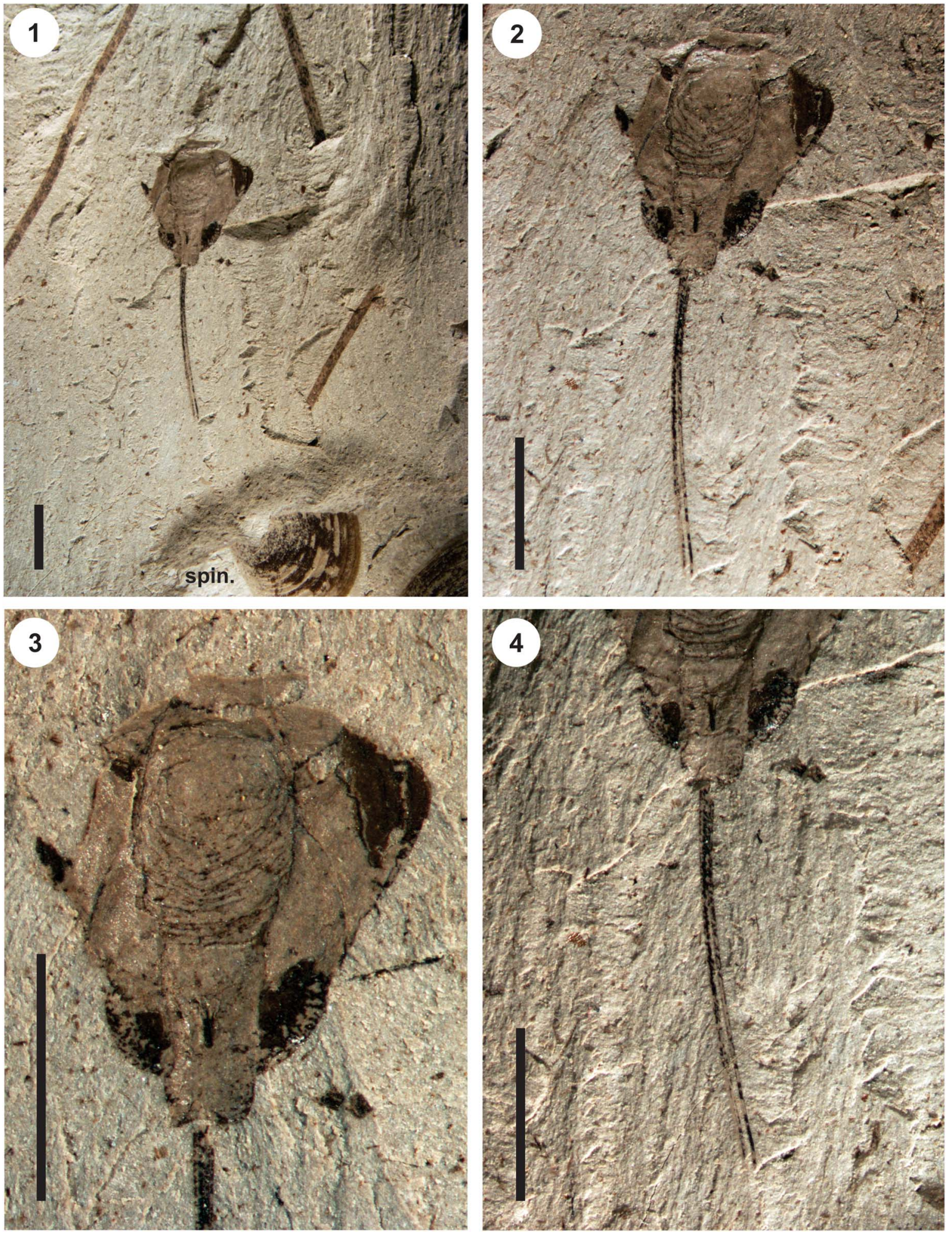

Figure 4. Duraznovis gallegoi n. gen. n. sp. from Potrerillos Formation, Cuyana Basin, Mendoza, Argentina, paratype, IANIGLA-PB 168, complete specimen in dorsoventral view: $(\mathbf{1})$ entire specimen; $(\mathbf{2}, \mathbf{3})$ detail showing the morphologic characters; (4) detail of posterior region and tail. spin. $=$ spinicaudatans. Scale bars $=2 \mathrm{~mm}$.

region (Fig. 5.2, Po), which ends in a long, styliform tail-like structure (Fig. 5.2, Ta), measuring in total $10.36 \mathrm{~mm}$ long. The specimen is dorsoventrally flattened with a partially preserved, elongated, guitar-shaped shield (Fig. 5.2, S), $4 \mathrm{~mm}$ long and $4.3 \mathrm{~mm}$ wide (if complete). The lateral margins of the shield are oblique to the median axis at an angle of $70^{\circ}$, although this specimen suffered slight lateral compression, judging from its asymmetry. The impressions of undetermined 
1

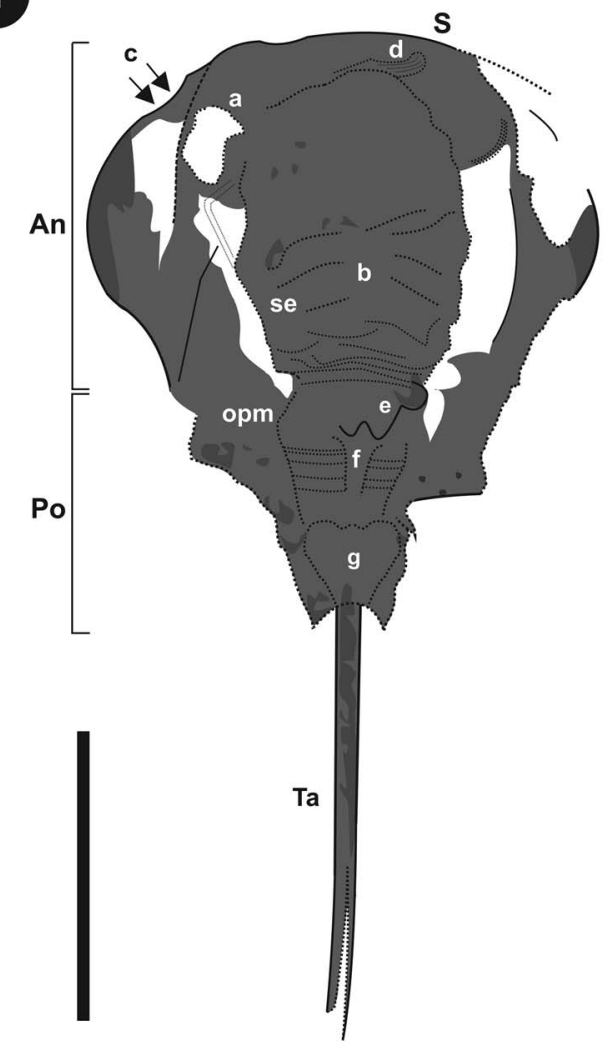

3

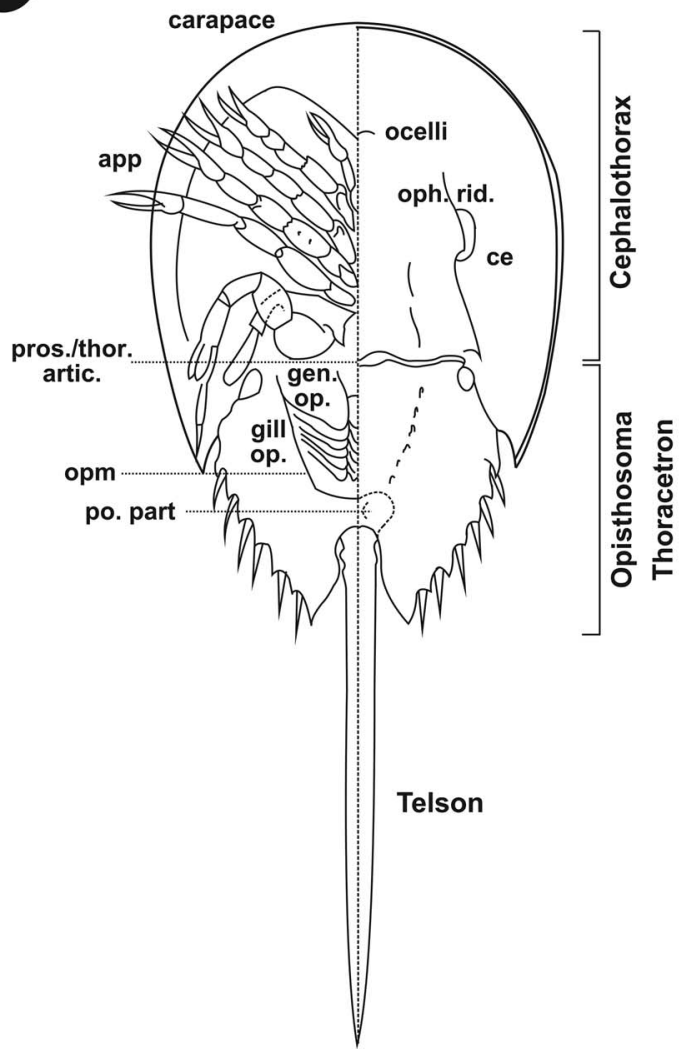

2

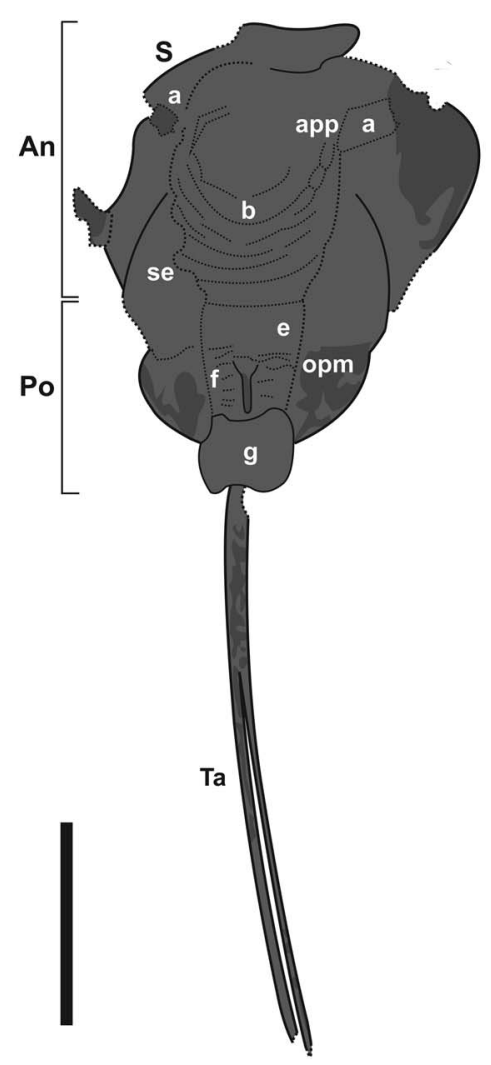

4

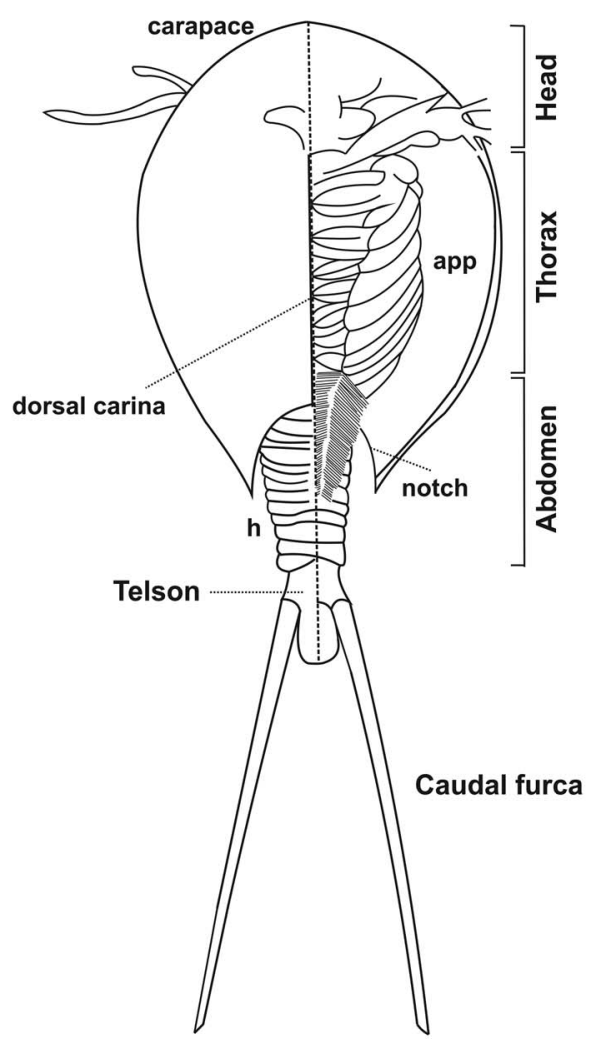


structures are visible on the upper part of the anterior section (Fig. 5.2, a). An area $(1.7 \mathrm{~mm})$ is visible, crossed by several furrows (Figs. 4, 5.2, b) that are probably pointing to the places where the appendages (Fig. 5.2, app) were attached. The posterior region is $1.8 \mathrm{~mm}$ long, unsegmented, trapezoidal, and apodous. This region ends in a long, styliform structure $(5.7 \mathrm{~mm})$ inserted in the middle of a rounded square area. This structure is slightly curved and more anteriorly divided than in the holotype specimen.

Etymology.-Dedicated to Dr. Oscar Florencio Gallego in recognition of his contributions to the fossil crustaceans of Argentina.

Measurements.-Holotype, IANIGLA-PB 203: The total length of the animal including the tail-like structure is (a) $=7 \mathrm{~mm}$; width $(b)=3.4 \mathrm{~mm}$; length $/$ width ratio $(c)=2.05 \mathrm{~mm}$; total length from the anterior margin of the shield to the posterior margin excluding tail-like structure $(\mathrm{d})=2.57 \mathrm{~mm}$. Paratype, IANIGLA-PB 168: $\mathrm{a}=10.36 \mathrm{~mm} ; \mathrm{b}=4.3 \mathrm{~mm} ; \mathrm{c}=2.41 \mathrm{~mm}$; $\mathrm{d}=4.3 \mathrm{~mm}$.

Remarks. - The peculiar morphology observed in Duraznovis gallegoi n. gen. n. sp. is considerably difficult in its interpretation and correct taxonomic allocation. However, the possession of a generalized arthropod morphology and a unique combination of characters similar to those of living and fossil representatives of xiphosurans (Chelicerata) and notostracans (Branchiopoda), e.g., body shape, differentiation of body into anterior and posterior regions, a shield, and a tail-like structure, make documentation of these specimens worthwhile.

\section{Discussion}

Comparison with other morphologically similar Arthropoda.Based on the morphological characters observed in Duraznovis gallegoi n. gen. n. sp. (Figs. 3, 4), affinities to either Xiphosura Latreille, 1802 (Chelicerata) (= Merostomata Dana, 1852) and Notostraca Sars, 1867 (Crustacea, Branchiopoda) can be inferred.

Duraznovis gallegoi n. gen. n. sp. (Figs. 3, 4) could be placed close to xiphosurans (Fig. 5.3) by the presence of a body differentiated into tagmatas, terminating in a long, styliform tail-like structure (Fig. 5.1, 5.2, Ta); large shield (Fig. 5.1, 5.2, S); and six thoracic segments (Fig. 5.1, 5.2, se) that probably bore six pairs of 'appendages,' ventrally attached to the shield (Dunlop and Selden, 1997) (Fig. 5.3). The anterior region (Fig. 5.1, 5.2, An) and posterior region (Fig. 5.1, 5.2, Po) in Duraznovis gallegoi n. gen. n. sp. could be considered analogous to the 'prosomal' dorsal shield (cephalothorax) and abdomen (opisthosoma/thoracetron) in xiphosurans, respectively (Fig. 5.3). The shield (Fig. 5.1, 5.2, S) in both xiphosurans and Duraznovis gallegoi $\mathrm{n}$. gen. $\mathrm{n}$. sp. has a semicircular anterior margin and lateral margins oblique to the median axis, covering the anterior region (Fig. 5.1, 5.2, An), but in Duraznovis gallegoi n. gen. n. sp., the shield is guitar-shaped, whereas in xiphosurans it has the shape of a horseshoe (Fig. 5.3). The holotype specimen (IANIGLA-PB 203, Figs. 3, 5.1) has an irregularity on the left margin of the shield (Fig. 5.1, c), like the cephalothoracic injuries found in extant xiphosurans (see Bicknell et al., 2018, fig. 2.5). Such injuries could be self-inflicted (from mating or predation), teratological (developmental and genetic), or pathological (disease or parasites). In both of our specimens, the impression of two undetermined structures are visible on the anterior section (Fig. 5.1, 5.2, a), similar to xiphosuran compound eyes (Fig. 5.3, ce), but these are too bulbous, not associated with an ophthalmic ridge, and differ in their position, and therefore are here left as undetermined.

Possible anterior muscle structures (Fig. 5.1, d) are observed in the holotype specimen, resembling those described in Yunnanolimulus luopingensis Zhang et al., 2009 (see Hu et al., 2017, fig. 4c, e), a xiphosuran from the Middle Triassic of China. A central area in Duraznovis gallegoi n. gen. n. sp. (Fig. 5.1, 5.2, b) resembles that of xiphosurans in the presence of six segments (Fig. 5.1, 5.2, se) that are probably related to the walking appendages (Fig. 5.3, app). The posterior region (Fig. 5.1, 5.2, Po) in Duraznovis gallegoi n. gen. n. sp. can be compared with the opisthosoma of xiphosurans (Fig. 5.3), however in Duraznovis gallegoi n. gen. n. sp., this region is more elongated than in xiphosurans, which could be a consequence of postmortem deformation. In both the holotype and paratype specimens, there is a broad area similar to the opisthosomal margin of xiphosurans (Fig. 5.1-5.3, opm). The abdomen of Duraznovis gallegoi $\mathrm{n}$. gen. n. sp. has a broad area (Fig. 5.1, 5.2, e) that could be interpreted as an equivalent to the genital operculum of xiphosurans (Fig. 5.3, gen. op.). Following, an area transversally crossed by numerous lineations could be indicating the position of the gills (Fig. 5.1, 5.2, f, 5.3, gill.op.). The distal placement of the gills in our specimens is in accordance with Lamsdell (2013), who stated that in aquatic chelicerates, the opisthosomal appendages are modified into flattened opercula that bear the respiratory organs ('book gills'). The posteriormost part of the abdomen in Duraznovis gallegoi n. gen. n. sp. ends in a heartshaped plate with sharp to rounded lateral extensions (Fig. 5.1, $5.2, \mathrm{~g}$ ), somewhat comparable to those observed in xiphosurans (Fig. 5.3, po. part). Lastly, the fossil specimens have long, styliform tail-like structure (Fig. 5.1, 5.2, Ta) analogous to the telson of xiphosurans (Fig. 5.3), although in Duraznovis gallegoi n. gen. n. sp., the tail is divided distally in holotype IANIGLA-PB 203, and more anteriorly in paratype IANIGLA-PB 168. The asymmetrical split occurring at different

\footnotetext{
Figure 5. Interpretative drawings: $(\mathbf{1 , 2})$ Duraznovis gallegoi $n$. gen. n. sp., showing the morphological characters preserved: (1) holotype, IANIGLA-PB 203; (2) paratype, IANIGLA-PB 168; (3) morphological features of xiphosurans (modified from Ruppert, 2004); and (4) morphological features of notostracans (modified from McLaughlin, 1980). $a=$ undetermined structures similar to xiphosuran compound eyes; $A n=$ anterior region; app $=$ appendages; $b=$ area related to the xiphosurans walking appendages; $\mathrm{c}=$ shield injuries; $\mathrm{ce}=$ compound eyes; $\mathrm{d}=$ ?muscle; $\mathrm{e}=\mathrm{broad}$ area perhaps related to genital operculum of xiphosurans; $\mathrm{f}=$ area transversely lineated perhaps indicating position of gills; $\mathrm{g}=$ abdominal plate; gen. op. $=$ genital operculum; gill op. $=$ gill opercula; $\mathrm{h}=$ abdominal segments oph. rid. $=$ ophthalmic ridges; $\mathrm{opm}=$ opisthosomal margin; $\mathrm{Po}=$ posterior region; po. part $=$ opisthosoma posterior part; pros. $/$ thor. artic. $=$ prosoma/thoracetron articulation; $\mathrm{S}=$ shield; $\mathrm{se}=$ thoracic segments; $\mathrm{Ta}=$ tail-like structure. Scale bars $=2 \mathrm{~mm}$.
} 
lengths of this structure in the two fossil specimens suggests that it could be taphonomic breakage rather than a taxonomic feature. Similarly, divided telsons in extant xiphosurans have been reported as teratological abnormalities (see Bicknell et al., 2018 , fig. 1), so this possibility should not be ruled out.

The main difference observed between Duraznovis gallegoi n. gen. n. sp. and other xiphosurans is their body size $(7-10 \mathrm{~mm})$, being smaller than all other known Triassic specimens, although not markedly differing from 'Paleolimulus' fuchsbergensis Hauschke and Wilde, 1987 from the Upper Triassic of northern Germany (12 mm long). The remaining species are considerably larger (21-146.5 mm), i.e., Dubbolimulus peetae Pickett, 1984 from Middle Triassic of Australia (21 mm); and Austrolimulus fletcheri Riek, 1955, Middle Triassic of Australia $(146.5 \mathrm{~mm})$. The variation of size observed in fossil xiphosurids could be explained by the great morphological disparity that they reached during Triassic times (Bicknell et al., 2019). Other typical morphological structures of xiphosurans that are not visible in our specimens are the opisthosomal spines or the genal spines (Fig. 5.3) (Dunlop and Selden, 1997; Lamsdell, 2013). Nevertheless, the absence of ornamentation in our specimens could be due to a taphonomic issue, because spines and other structures are most likely to be lost during the process of fossilization (Bicknell et al., 2018).

At a different level, Duraznovis gallegoi $n$. gen. n. sp. presents a 'notostracan-like' (Crustacea, Branchiopoda) overall appearance (Figs. 3-5), e.g., the presence of a large shield (Fig. 5.1, 5.2, S) that is strongly drawn out laterally and posteriorly; an elongate trunk that carries the appendages (Fig. 5.1, 5.2, 5.4, app); and a long, tail-like structure analogous to the caudal furca of some members of the extant family Triopsidae Keilhack, 1909 (Fig. 5.1, 5.2, Ta; 5.4). At closer look, however, notostracans have an elongated shield with a rounded-acute proximal margin (Fig. 5.4), differing from the guitar-shaped shield of Duraznovis gallegoi n. gen. $n$. sp. Another difference between these specimens and notostracans refers to total size; extant adult notostracans range from $1-10 \mathrm{~cm}$ in length (Rogers, 2009). The ventral organization also shows variations; for example, the number of appendages on the thorax of both fossil and extant notostracans ranges from 10-80 (Rogers, 2009; Lagebro et al., 2015), markedly contrasting from the potential presence of only six pairs in Duraznovis gallegoi n. gen. n. sp. Additionally, the abdomen in notostracans is composed of several segments, surpassing the posterior limit of the protective shield and leaving the more distal segments exposed (Fig. 5.4, h). In comparison, the abdomen of Duraznovis gallegoi n. gen. n. sp. is shorter and almost completely covered by the shield. However, Hegna (2012) suggested that some abdominal segments in notostracans can be lost during the fossilization process, or potentially, shortened by desiccation. Because both of our fossil specimens are complete and articulated, we consider this as highly unlikely. On the other hand, Wagner et al. (2018) mentioned that a short trunk is probably related with early juvenile notostracans stages. Unfortunately, the developmental stages of our specimens are hard to tell from the fossils, because no gonads are recognized, and more specimens are needed to show size variations that could clarify this point. Lastly, the long, styliform tail-like structure visible in Duraznovis gallegoi n. gen. n. sp. (Fig. 5.1-5.2, Ta) is centrally inserted to the heart-shaped plate (Fig. 5.1, 5.2, f), whereas in notostracans, the 'tail' is composed of two caudal furcas laterally attached to a telson (Fig. 5.4).

In summary, these fossils show a combination of features found in two disparate arthropod groups, i.e., Xiphosura and Notostraca, making correct taxonomic allocation difficult. Therefore, until additional, better-preserved specimens are recovered, which can shed light about development stages, reproductive structures, or even clarify the still-undefined structures mentioned herein, we prefer to maintain their systematic classification as indeterminate.

Taphonomic and paleoenvironmental implications.Duraznovis gallegoi n. gen. n. sp. comes from Facies Association A2 described by Lara et al. (2017), which refers to ponds or swamps developed within the shallow embayments during deltaic flooding pulses in the lower delta plain. These ponds never dried out completely, as suggested by the absence of desiccation cracks, but their shallow, usually submerged substrates were probably episodically exposed, as the presence of incipient paleosols indicate. Moreover, numerous Euestheria forbesi (Crustacea: Spinicaudata) specimens (Figs. 3, 4, spin.) recorded in this facies present wrinkles in their valves, producing desiccation patterns similar to those described by Astrop (2014) for the upper Permian spinicaudatan Megasitum harmonicum Novojilov, 1970 from Kazakhstan.

The material studied herein was found associated with an abundant well-preserved flora, a rich fauna of spinicaudatan crustaceans (Figs. 3, 4, spin.), numerous diverse insects, and a few fish remains (Lara et al., 2017). The low abundance of these enigmatic arthropods at the Quebrada del Durazno locality might be related to the presence of fishes in the water pools, which probably acted as top predators in these habitats. Other explanations could be that the high abundance of spinicaudatans inhibited the diversification of the group by competition for the same resources; or that during extreme flooding events, these specimens were transported accidentally from farther areas. Finally, we do not rule out a potential collection or taphonomic bias.

The faunistic associations of spinicaudatans with notostracans, as well as spinicaudatans with xiphosurans, have been previously recorded from other Triassic localities worldwide. The former association was reported for ephemeral pool communities from the Middle Triassic of the Grès à Voltzia Formation in France (Gall and Grauvogel-Stamm, 2005), whereas taphocenosis with both xiphosurans and spinicaudatans have been described from freshwater to brackish-water environments from the Middle Triassic of southern Tunisia (Błażejowski et al., 2017).

In addition to the similar morphological characteristics mentioned above, Duraznovis gallegoi n. gen. n. sp. was found in a paleoenvironment not very different from those registered for notostracans and xiphosurans. With a fossil record starting in the Devonian, notostracans have developed a wide range of forms that inhabit almost exclusively temporary freshwater bodies on all continents (including Antarctica) (Gueriau et al., 2016), being occasionally found in marine environments (Adamowicz and Purvis, 2005; Olesen, 2007; Hegna, 2012; 
Rogers and Padhye, 2015). On the other hand, the record of xiphosurans extends to the Lower Ordovician (Van Roy et al., 2010). This group of arthropods is nowadays found living in marginal environments, and the same is observed for their fossil counterparts, recovered from marginal marine to brackish paleoenvironments (Fisher, 1979; Babcock et al., 2000), and more rarely from freshwater settings (Pickett, 1984; Błażejowski et al., 2017). Lamsdell (2016) suggested that xiphosurans have independently colonized the nonmarine realm many times during their evolutionary history, like Psammolimulus gottingensis Lange, 1923, from the Triassic of Germany, which inhabited freshwater floodplain habitats along braided river systems (Lerner et al., 2017). Therefore, the freshwater paleoenvironment at the Quebrada del Durazno locality would not be a barrier to finding xiphosurans. If in the near future new fossils validate Duraznovis gallegoi $\mathrm{n}$. gen. $\mathrm{n}$. sp. as belonging to Xiphosurida, this site will add new evidence of freshwater xiphosurans as a result of the post-Permian extinction environmental pressure (Foster and Twitchett, 2014; Lamsdell, 2016; Błażejowski et al., 2017).

The complete, articulated state and the quality preservation of Duraznovis gallegoi n. gen. n. sp. suggest that the specimens were quickly covered by sediments, protecting them from postmortem processes and/or biological attacks. An analogous example was given by Lagebro et al. (2015), who mentioned that the lack of damage in fossil notostracans implies in situ deposition where little or no scavenging or turbulence occurred. Additionally, Hegna (2012) evaluated how notostracans tolerated disarticulation and fragmentation through decay experiments under laboratory conditions (euthanized by asphyxiation, covered with freshwater in a tray at room temperature; some specimens were dried to assess the effects of desiccation) showing that after 16 days from their death, no fully articulated animals remained. For the xiphosurans, Babcock et al. (2000) mentioned that only under exceptional circumstances (i.e., Lagerstätten deposits), the cuticular exoskeleton and disarticulation of body parts will remain relatively low. Likewise, the remarkable preservation as a 3D mold of the holotype of Duraznovis gallegoi n. gen. n. sp. suggests a different taphonomic history from spinicaudatans recorded at the same site (Figs. 3, 4, spin.). The latter taxa are represented by isolated and poorly preserved prints of valves (dorsal shields), which probably corresponded to postmortem disarticulated bodies, deposited in a water depression. The small size observed in Duraznovis gallegoi n. gen. n. sp. points to a juvenile instar stage rather than a mature adult, although this cannot be fully ascertained until we have more specimens that help us to understand their complete life cycle. For instance, Błażejowski (2015) mentioned that juvenile xiphosurids spend their first years in shallow waters, rapidly increasing in size before moving to deeper waters. Unfortunately, ontogenetic changes in the fossil record are enormously difficult to observe from a limited number of specimens (Allen and Feldmann, 2005).

\section{Conclusions}

Duraznovis gallegoi $\mathrm{n}$. gen. $\mathrm{n}$. sp. is an enigmatic arthropod from the Triassic of Argentina. The extremely unusual morphology observed indicates that it is a new species to science, and therefore its documentation is of utmost interest. Duraznovis gallegoi n. gen. n. sp. closely resembles in its morphological and paleoecological characteristics (e.g., overall body shape, differentiation of the tagmas, and presence of a shield), living and fossil representatives of xiphosurans and notostracans, two completely different arthropod groups with convergent body structures. However, the combination of their reduced size, the guitar-shaped shield without ornamentation, a tail-like structure divided and centrally inserted to the posterior end of the body, and few thoracic and abdominal segments make correct allocation of these specimens uncertain. Thus, we prefer to maintain the taxonomic position as indeterminate until further specimens are recovered.

These new specimens reveal that the microenvironment at the Quebrada del Durazno locality during Triassic times had an unusual and diverse freshwater fauna that awaits further discoveries. We anticipate that extensive fieldwork and continued research and identification of new specimens will allow us to increase information on invertebrate community structure, also providing a unique opportunity for understanding ecosystem evolution during the Upper Triassic in this part of the world.

\section{Acknowledgments}

Grateful acknowledgment is extended to E. Sosa and J. Bustos for facilitating access to the Triassic strata exposed at their farm, E. Zavattieri for editing some of the images, and M. Miñana for technical assistance. We also thank T. Hegna, D. Audo, and two anonymous reviewers for their suggestions and comments, which improved the final version of this manuscript. This work was supported by the Agencia Nacional de Promoción Científica y Tecnológica (ANPCyT) grants PICT 2014-2546 (PI: A.M. Zavattieri), PICT 2016-1954 (PI: M.B. Lara), PICT 2016-0431 (PI: B. Cariglino), Secretaría General de Ciencia y Técnica, Universidad Nacional del Nordeste (Grant No. Q006-2014), and CONICET PIP 2014-2016 No. $11220130100317 \mathrm{CO}$.

\section{References}

Adamowicz, S.J., and Purvis, A., 2005, How many branchiopod crustacean species are there? Quantifying the components of underestimation: Global Ecology and Biogeography, v. 14, p. 455-468, doi:10.1111/j.1466822X.2005.00164.X.

Allen, J.P., and Feldmann, R.M., 2005, Panduralimulus babcocki n. gen. and sp., a new limulacean horseshoe crab from the Permian of Texas: Journal of Paleontology, v. 79, p. 594-600, doi:10.1666/0022-3360(2005) $079<0594:$ PBNGAS $>2.0$. CO; 2 .

Astrop, T.I., 2014, The evolutionary dynamics of sexual systems in deep time: an integrated biological and paleontological approach [Ph.D. thesis]: Akron, Ohio, University of Akron, $233 \mathrm{p}$.

Babcock, L.E., Merriam, D.F., and West, R.R., 2000, Paleolimulus, an early limuline (Xiphosurida), from Pennsylvanian-Permian Lagerstätten of Kansas and taphonomic comparison with modern Limulus: Lethaia, v. 33 , p. 129-141, doi:10.1080/00241160025100017.

Barredo, S.P., 2012, Geodynamic and tectonostratigrafic study of a continental rift: The Triassic Cuyana Basin, Argentina, in Sharkov, E., ed., TectonicsRecent Advances, v. 346, p. 99-130.

Bicknell, R.D., Žalohar, J., Miklavc, P., Celarc, B., Križnar, M., and Hitij, T., 2019, A new limulid genus from the Strelovec Formation (Middle Triassic, Anisian) of northern Slovenia: Geological Magazine, doi:10.1017/ S0016756819000323.

Bicknell, R.D.C., Pates, S., and Botton, M.L., 2018, Abnormal xiphosurids, with possible application to Cambrian trilobites: Palaeontologia Electronica, v. 21, p. 1-17, doi: $10.26879 / 866$. 
Błażejowski, B., 2015, The oldest species of the genus Limulus from the Late Jurassic of Poland, in Carmichael, R.H., Botton, M.L., Shin, P.K.S., and Cheung, S.G., eds., Changing Global Perspectives on Horseshoe Crab Biology, Conservation and Management: Cham, Switzerland, Springer International Publishing, p. 3-14, doi:10.1007/978-3-319-19542-1_1.

Błażejowski, B., Niedźwiedzki, G., Boukhalfa, K., and Soussi, M., 2017, Limulitella tejraensis, a new species of limulid (Chelicerata, Xiphosura) from the Middle Triassic of southern Tunisia (Saharan Platform): Journal of Paleontology, v. 91, p. 960-967, doi:10.1017/jpa.2017.29.

Camacho, H.H., 1995, Los crustáceos branquiopodos: in Stipanicic, P.N., and Hünicken, M.A, eds., Contribuciones a la Palaeophytologia Argentina, Partes 1 a 7I: Actas de la Academia Nacional de Ciencias (Córdoba), v.11, p. $233-234$

Camacho, H.H., and Del Río, C.J., 2007, Gastropoda, in Camacho, H.H., and Longobucco, M.I., eds., Los Invertebrados Fósiles: Buenos Aires, Fundación de Historia Natural Félix de Azara, p. 323-376.

Carignano, A.P., and Zavattieri, A.M., 2018, Darwinulocopina (Ostracoda) triásicos de la Formación Cerro de Las Cabras, Cuenca Cuyana, Mendoza, Argentina: Resultados preliminaries, in Reunión de Comunicaciones de la Asociación Paleontológica Argentina (RCAPA), Puerto Madryn, Argentina, 21-23 de Noviembre de 2018, Libro de Resúmenes: Buenos Aires, Asociación Paleontológica Argentina, p. 49

Carignano, A.P., Echeverría, J., and Zavattieri, A.M., 2018, Posible dimorfismo sexual en los Darwinulocopina del Triásico Medio de Mendoza, in Reunión de Comunicaciones de la Asociación Paleontológica Argentina (RCAPA), Puerto Madryn, Argentina, 21-23 de Noviembre de 2018, Libro de Resúmenes: Buenos Aires, Asociación Paleontológica Argentina, p. 50

Chebli, G.A., Labayén, I.L., Laffitte, G.A., and Rosso, M.R., 1984, Materia orgánica, ambiente deposicional y evaluación oleogenética de la Cuenca Cuyana, in Relatorio del Congreso Geológico Argentino, 9th, Bariloche, Argentina, Actas 7: Buenos Aires, Asociación Geológica Argentina, Servicio Geológico Nacional, p. 68-85

Chebli, G.A., Ploszkiewicz, J.V., and Azpiroz, G.M., 2001, El sistema Triásico y los hidrocarburos, in Artabe, A.E., Morel, E.M. and Zamuner, A.B., eds., El Sistema Triásico en la Argentina: La Plata, Argentina, Fundación Museo de La Plata 'Francisco Pascasio Moreno,' p. 283-315.

Covacevich, V., Pino, P.L., and Fuenzalida, G., 1988, Presencia del género Triops Shrank, 1803 (Arthropoda: Branchiopoda) en la Formación Pular (Paleozoico superior), Región de Antofagasta, Chile, in Congreso Geológico Chileno, 5th, Santiago, Chile: Santiago, Comunicaciones (Universidad de Chile), Departamento de Geología, Facultad de Ciencias Físicas y Matemáticas de la Universidad de Chile, v. 5, p. 341-358.

Dana, J.D., 1852, Crustacea, Parts 1 and 2; U. S. Exploring Expedition During the Years 1838, 1839, 1840, 1841, 1842, Under the Command of Charles Wilkes, U.S.N.: Philadelphia, C. Sherman, v. 13, p. 1-1618.

Dunlop, J.A, and Selden, P.A., 1997, The early history and phylogeny of the chelicerates, in Fortey, R.A., and Thomas, R.H., eds., Arthropod relationships: Systematics Association Special Volumes Series, v. 55, p. 221-235.

Fisher, D.C., 1979, Evidence for subaerial activity of Euproops danae (Merostomata, Xiphosurida), in Nitecki, M.H., ed., Mazon Creek Fossils: New York, Academic Press, p. 379-447.

Foster, W.J., and Twitchett, R.J., 2014, Functional diversity of marine ecosystems after the late Permian mass extinction event: Nature Geoscience, v. 7 , p. $233-238$, doi: $10.1038 /$ ngeo 2079 .

Gall, J.C., and Grauvogel-Stamm, L., 2005, The early Middle Triassic 'Grès à Voltzia' Formation of eastern France: A model of environmental refugium: Paléontologie Générale (Paléoécologie), v. 4, p. 637-652, doi:10.1016/ j.crpv.2005.04.007.

Gallego, O.F., 1992, Conchostracos triásicos de Mendoza y San Juan, Argentina: Ameghiniana, v. 2, p. 159-175.

Gallego, O.F., 1999, Estudio sistemático de las faunas de conchóstracos triásicos de la República Argentina [PhD thesis]: Córdoba, Argentina, Universidad Nacional de Córdoba, $210 \mathrm{p}$

Gallego, O.F., 2005, First record of the family Palaeolimnadiopseidae Defretin Le-Franc, 1965 (Crustacea-Conchostraca) in the Triassic of Argentina: Journal of South American Earth Science, v. 18, p. 223-231, doi:10.1016/ j.jsames.2004.10.002.

Gallego, O.F., Zavattieri, A.M., and López-Arbarello, A., 2004, Conchóstracos y restos de peces de la localidad tipo de la Formación Río Mendoza (Triásico Medio), provincia de Mendoza, Argentina: Ameghiniana, v. 41, p. 289-301.

Gallego, O.F., Rébori, L.O., Zavattieri, A.M., Sinitshenkova, N., Lara, M.B., and Martins-Neto, R.G., 2011, The most ancient Platyperlidae (Insecta-Perlida = Plecoptera) from the early Upper Triassic deposits in southern South America: Ameghiniana, v. 48, p. 447-461.

Griffin, M., and Varela, A.N., 2012, Systematic palaeontology and taphonomic significance of the mollusc fauna from the Mata Amarilla Formation (lower Upper Cretaceous), southern Patagonia, Argentina: Cretaceous Research, v. 37, p. 164-176, doi:10.1016/j.cretres.2012.03.016.
Gueriau, P., Rabet, N., Gaël, C., Lagebro, L., Vannier, J., Derek, E.G., Briggs, D.E.G., Charbonnier, S., Olive, S., and Béthoux, O., 2016, A 365-million-year-old freshwater community reveals morphological and ecological stasis in branchiopod crustaceans: Current Biology, v. 26, p. 383-390, doi:10.1016/jcub.2015.12.039.

Hauschke, N., and Wilde, V., 1987, Paleolimulus fuchsbergensis n. sp. (Xiphosura, Merostomata) aus der oberen Trias von Nordwestdeutschland, mit einer Übersicht zur Systematik und Verbreitung rezenter Limuliden: Paläontologische Zeitschrift, v. 61, p. 87-108.

Hegna, T.A., 2012, Phylogeny and fossil record of branchiopod crustaceans: An integrative approach [Ph.D. thesis]: New Haven, Connecticut, Yale University, $262 \mathrm{p}$.

Hu, S., Zhang, Q., Feldmann, R.M., Benton, M.J., Schweitzer, C.E., Huang, J., Wen, W., Zhou, C., Xie, T., Lü, T., and Hong, S., 2017, Exceptional appendage and soft-tissue preservation in a Middle Triassic horseshoe crab from SW China: Scientific Reports, v. 7, no. 14112, doi:10.1038/ s41598-017-13319-x

Keilhack, L., 1909, Phyllopoda, in Brauer, F., ed., Die Süsswasserfauna Deutschlands: Eine Exkursionsfauna, Heft 10: Jena, Germany, Gustav Fischer, p. 1-112.

Jones, T.R. 1863, A monograph of the fossil Estheriae: Monographs of the Palaeontographical Society, London, $134 \mathrm{p}$

Lagebro, L., Gueriau, P., Hegna, T.A., Rabet, N., Butler, A.D., and Budd, G.E., 2015, The oldest notostracan (Upper Devonian Strud locality, Belgium): Palaeontology, v. 58, p. 497-509, doi:10.1111/pala.12155.

Lamsdell, J.C., 2013, Revised systematics of Palaeozoic 'horseshoe crabs' and the myth of monophyletic Xiphosura: Zoological Journal of the Linnean Society, v. 167, p. 1-27, doi:10.1111/j.1096-3642.2012.00874.x.

Lamsdell, J.C., 2016, Horseshoe crab phylogeny and independent colonizations of fresh water: Ecological invasion as a driver for morphological innovation: Palaeontology, v. 59, p. 181-194, doi:10.1111/pala.12220.

Lange, E.W., 1923, Über neue Fossilfunde aus der Trias von Göttingen: Zeitschrift der Deutschen Geologischen Gesellschaft, v. 74, p. 162-168.

Lara, M.B., 2016, La paleoentomofauna triásica del Cerro Cacheuta (Cuenca Cuyana): Estudio sistemático, paleoecológico y su relación con otras asociaciones coetáneas [Ph.D. thesis]: Córdoba, Argentina, Universidad Nacional de Córdoba, 414 p.

Lara, M.B., and Aristov, D., 2016, First records of Geinitziidae family (Insecta: Grylloblattida) from Upper Triassic of Argentina (Mendoza): Alcheringa, An Australasian Journal of Palaeontology, v. 41, p. 207-214, doi:10.1080/ 03115518.2016.1206323

Lara, M.B., and Lukashevich, E.D., 2013, The first Triassic Diptera (Insecta) from South America, with review of Hennigmatidae: Zootaxa, v. 3710, p. 81-92, doi:10.11646/zootaxa.3710.1.6.

Lara, M.B., and Wang, B., 2016, New hemipteran insects (Eoscarterellidae, Scytinopteridae and Protopsyllidiidae) from the Upper Triassic Potrerillos Formation of Mendoza, Argentina: Paläontologische Zeitschrift, v. 90, p. 49-61, doi:10.1007/s12542-016-0286-8.

Lara, M.B., Rasnitsyn, A.P. and Zavattieri, A.M., 2014, Potrerilloxyela menendezi gen. et sp. nov. from the Late Triassic of Argentina: The oldest representative of Xyelidae (Hymenoptera: Symphyta) for Americas: Paleontological Journal, v. 48, p. 182-190, doi:10.7868/S0031031X1402007X.

Lara, M.B., Bashkuev, A., and Wang, B., 2015, Argentinopanorpa miguezi gen. et sp. nov.: First record of Triassic Mecoptera (Permochoristidae) from the Cuyo Basin (Mendoza, Argentina): Alcheringa, An Australasian Journal of Palaeontology, v. 39, p. 175-180, doi:10.1080/03115518.2015. 964059.

Lara, M.B., Cariglino, B., and Zavattieri, A.M., 2017, Palaeoenvironmental interpretation of an Upper Triassic deposit in southwestern Gondwana (Argentina) based on an insect fauna, plant assemblage, and their interactions: Palaeogeography, Palaeoclimatology, Palaeoecology, v. 476, p. 163-180, doi:10.1016/j.palaeo.2017.03.029.

Latreille, P.A., 1802, Histoire Naturelle, Générale et Particulière des Crustacés et des Insectes, Volume 3: Paris, Dufart, $467 \mathrm{p}$.

Latreille, P.A., 1829, Les Crustacés, les Arachnides et les Insectes, distributes en Families Naturelles: Paris, Chez Déterville, $581 \mathrm{p}$.

Lerner, A.J., Lucas, S.G., and Lockley, M., 2017, First fossil horseshoe crab (Xiphosurida) from the Triassic of North America: Neues Jahrbuch für Geologie und Paläontologie-Abhandlungen, v. 286, p. 289-302, doi:10.1127/ njgpa/2017/0702.

López Gamundí, O.R., 1994, Facies distribution in an asymmetric half graben: The northern Cuyo Basin (Triassic), western Argentina, in International Sedimentological Congress, 14th, Recife, Brazil, Abstracts S1: Recife, International Association of Sedimentologists, Federal University of Pernambuco, and Petróleo Brasileiro (Petrobrás), p. 6-7.

López Gamundí, O.R., 2010, Sedimentation styles and variability of organic matter types in the Triassic, non-marine half-grabens of west Argentina: Implications for petroleum systems in rift basins: Petroleum Geoscience, v. 16, p. 267-272, doi:10.1144/1354-079309-912. 
Martins-Neto, R.G., and Gallego, O.F., 2009, The Triassic insect fauna from Argentina: Blattoptera and Coleoptera from Ischichuca Formation (Bermejo Basin) La Rioja province: Ameghiniana, v. 46, p. 361-372.

Martins-Neto, R.G., Gallego, O.F., and Melchor, R.N., 2001, The first record of kazacharthids (Branchiopoda) in the Triassic of South America: Ameghiniana, v. 38, p. 36-37.

Martins-Neto, R.G., Gallego, O.F., and Melchor, R.N., 2003, The Triassic insect fauna from South America (Argentina, Brazil and Chile): A checklist (except Blattoptera and Coleoptera) and descriptions of new taxa: Acta Zoologica Cracoviensia, v. 46, p. 229-256.

Martins-Neto, R.G., Mancuso, A.C., and Gallego, O.F., 2005, The Triassic insect fauna from Argentina: Blattoptera from Los Rastros Formation (Bermejo Basin), La Rioja Province: Ameghiniana, v. 42, p. 705-723.

Martins-Neto, R.G., Gallego, O.F., and Mancuso, A.C., 2006a, The Triassic insect fauna from Argentina: Coleoptera from Los Rastros Formation (Bermejo Basin), La Rioja Province: Ameghiniana, v. 43, p. 591-609.

Martins-Neto, R.G., Brauckmann, C., Gallego, O.F., and Carmona, M.J., 2006b, The Triassic insect fauna from Argentina: Blattoptera, Glosselytrodea, Miomoptera, Auchenorrhyncha, and Coleoptera from the Los Rastros Formation (Bermejo Basin), Los Chañares locality (La Rioja Province): Clausthaler Geowissenschaften, v. 5, p. 1-9.

Martins-Neto, R.G., Gallego, O.F., and Zavattieri, A.M., 2007, A new Triassic insect fauna from Cerro Bayo, Potrerillos (Mendoza Province, Argentina): With descriptions of new taxa (Insecta: Blattoptera and Coleoptera): Alcheringa, An Australian Journal of Paleontology, v. 31, p. 199-213, doi:10.1080/03115510701305173.

Martins Neto, R.G., Gallego, O.F., and Zavattieri, A.M., 2008, The Triassic insect fauna from Argentina: Coleoptera, Hemiptera and Orthoptera from the Potrerillos Formation, south of Cerro Cacheuta, Cuyana Basin: Alavesia, v. 2, p. 47-58.

McLaughlin, P.A., ed., 1980, Comparative Morphology of Recent Crustacea: San Francisco, California, W. H. Freeman and Company, 177 p.

Morton, L.S., and Herbst, R., 2001, Nuevas especies del género Diplodon Spix (Bivalvia, Unionidea) del Jurásico Medio (Formación La Matilde), provincia de Santa Cruz, Argentina: Revista del Museo Argentino de Ciencias Naturales, v. 3, p. 159-164.

Novojilov, N., 1970, [Extinct Limnadioidea (Conchostraca-Limnadioidea)]: Moscow, Nauka, 238 p. (in Russian)

Olesen, J., 2007, Monophyly and phylogeny of Branchiopoda, with focus on morphology and homologies of branchiopod phyllopodous limbs: Journal of Crustacean Biology, v. 27, p. 165-183, doi:10.1651/S-2727.1.

Papú, O.H., 1993, Nuevos hallazgos del género Grapnelispora (Stover \& Patridge) en la Formación Loncoche de Ranquil-Co, Cretácico Superior en la provincia de Mendoza, Argentina: Ameghiniana, v. 30, p. 143-147.

Parras, A., and Griffin, M., 2013, Late Cretaceous (Campanian/Maastrichtian) freshwater to restricted marine mollusc fauna from the Loncoche Formation, Neuquén Basin, west-central Argentina: Cretaceous Research, v. 40, 190 206, doi:10.1016/j.cretres.2012.07.002.

Pickett, J.W., 1984, A new freshwater limuloid from the Middle Triassic of New South Wales: Palaeontology, v. 27, p. 609-621.

Ramos, V.A., 1992, Control geotectónico de las cuencas triásicas de Cuyo: Boletín de Informaciones Petroleras, v. 9, p. 2-9.

Riek, E.F., 1955, A new xiphosuran genus from the Triassic sediments at Brookvale, New South Wales: Records of the Australian Museum, v. 23, p. 281-282.

Rogers, D.C., 2009, Branchiopoda (Anostraca, Notostraca, Laevicaudata, Spinicaudata, Cyclestherida), in Likens, G.F., ed., Encyclopedia of Inland Waters, Volume 2: Oxford, UK, Elsevier, p. 242-249.

Rogers, D.C., and Padhye, S., 2015, Review of the large branchiopod crustacean fauna of the Indian subcontinent (Anostraca, Notostraca, Laevicaudata, Spinicaudata, Cyclestherida): Journal of Crustacean Biology, v. 35, p. 392-406, doi:10.1163/1937240X-00002327.

Ruppert, E.E., ed., 2004, Invertebrate Zoology: A Functional Evolutionary Approach: Belmont, California, Thomson-Brooks/Cole, 963 p.

Rusconi, C., 1946a, Nuevos peces Triásicos de El Challao, Mendoza: Revista de la Sociedad de Historia y Geografía de Cuyo, v. 1, p. 1-15.
Rusconi, C., 1946b, Nuevos peces Triásicos de Uspallata: Revista de la Sociedad de Historia y Geografía de Cuyo, v. 141, p. 185-190.

Rusconi, C., 1947, Acerca de Estheria minoprioi (Ostracoda) de Mendoza: Boletin de la Facultad de Ciencias Físicas y Naturales, v. 9, p. 753-758.

Rusconi, C., 1948a, Algunas especies de Estherias del Triásico en Mendoza: Revista del Museo de Historia Natural, v. 2, p. 99-202.

Rusconi, C., 1948b, Apuntes sobre el Triásico y el Ordovícico de El Challao, Mendoza: Revista del Museo de Historia Natural, v. 2, p. 165-198.

Sars, G.O., 1867, Histoire Naturelle des Crustacés d'Eau Douce de Norvège: Les Malacostracés: Christiania [Copenhagen], Chr. Johnsen, 146 p.

Schrank, F., 1803, Favna Boica: Durchgedachte Geschichte der in Baiern Einheimischen und Zahmen Thiere, Volume 3: Landshut, Germany, Philipp Krüll, 372 p.

Shen, Y.B., Gallego, O.F., and Zavattieri, A.M., 2001, A new conchostracan genus from Triassic Potrerillos Formation, Argentina: Acta Geologica Leopoldensia, v. 24, p. 227-236.

Spalletti, L.A., Fanning, C.M., and Rapela, C.W., 2008, Dating the Triassic continental rift in the southern Andes: The Potrerillos Formation, Cuyo Basin, Argentina: Geologica Acta, v. 6, p. 267-283.

Stipanicic, P.N., and Zavattieri, A.M., 2002, Grupo Uspallata, in Stipanicic, P.N., and Marsicano, C.A., eds., Léxico Estratigráfico de la Argentina, Volume 8, Triásico: Asociación Geológica Argentina, Serie B (Didáctica y Complementaria), v. 26, p. 290-294.

Tasch, P., 1987, Fossil Conchostraca of the Southern Hemisphere and continental drift, palaeontology, biostratigraphy and dispersal: Memoir of the Geological Society of America, v. 165, p. 1-290.

Tassi, L.V., 2016, Estudio de la fauna de Spinicaudata a través del Triásico de Argentina y su recuperación luego del evento de extinción Permo-Triásico [Ph.D. thesis]: Córdoba, Argentina, Universidad Nacional de Córdoba, 261 p.

Tassi, L.V., Monti, M., Gallego, O.F., Zavattieri, A.M., and Lara, M.B., 2013, The first spinicaudatan (Crustacea-Diplostraca) from the Permo-Triassic continental sequences in South America and its paleoecological context: Alcheringa, An Australasian Journal of Palaeontology, v. 37, p. 189-201, doi:10.1080/03115518.2013.736793.

Tassi, L.V., Gallego, O.F., and Zavattieri, A.M., 2015, Triassic spinicaudatan fauna from the Cerro de Las Cabras Formation (Cuyo Basin), Mendoza Province (Argentina): Description of new species and revision of previous records: Ameghiniana, v. 52, p. 241-264.

Uliana, M.A., and Biddle, K.T., 1988, Mesozoic-Cenozoic paleogeographic and geodynamic evolution of southern South America: Revista Brasileira de Geografia, v. 18, p. 172-190.

Van Roy, P., Orr, P.J., Botting, J.P., Muir, L.A., Vinther, J., Lefebvre, B., el Hariri, K., and Derek, E.G., 2010, Ordovician faunas of Burgess Shale type: Nature, v. 465, p. 215-218, doi:10.1038/nature09038.

Wagner, P., Haug, J.T., Sell, J., and Haug, C., 2018, A fossil crustacean from the Upper Triassic of southern Germany with kazacharthran affinities: Paleontological Research, v. 22, p. 57-64, doi:10.2517/2017PR010.

Zavattieri, A.M., and Batten, D.J., 1996, Miospores from Argentinian Triassic deposits and their potential for intercontinental correlation, in Jansonius, J., and McGregor, D.C., eds., Palynology: Principles and Applications: Dallas, Texas, American Association of Stratigraphic Palynologists Foundation, p. 767-778.

Zavattieri, A.M., and Prámparo, M.B., 2006, Freshwater algae from the Upper Triassic Cuyana Basin of Argentina: Palaeoenvironmental implications: Palaeontology, v. 49, p. 1185-1209, doi:10.1111/j.14754983.2006.00596.x.

Zavattieri, A.M., and Rojo, L.D., 2005, Estudio microflorístico de las Formaciones Potrerillos y Cacheuta (Triásico) en el sur del cerro Cacheuta, Mendoza, Argentina, Parte 2: Ameghiniana, v. 42, p. 513-534.

Zhang, Q.Y., Hu, S.X., Zhou, C.Y., Lv, T., and Bai, J.K., 2009, New occurrence of Xiphosura in China: Progress in Natural Science, v. 19, p. 1090-1093.

Accepted: 30 September 2019 